\title{
Working the Crowd: Improvisational Entrepreneurship and Equity Crowdfunding in Nascent Entrepreneurial Ventures
}

Ross Brown, University of St Andrews

Suzanne Mawson, University of Stirling

Alexander Rowe, University of St Andrews

Colin Mason, University of Glasgow

Brown R, Mawson S, Rowe A \& Mason C (2018) Working the Crowd: Improvisational Entrepreneurship and Equity Crowdfunding in Nascent Entrepreneurial Ventures, International Small Business Journal, 36 (2), pp. 169-193.

Copyright (C) The Author(s) 2017. Reprinted by permission of SAGE Publications.

\begin{abstract}
Equity crowdfunding has rapidly established itself as an important part of the funding landscape for nascent entrepreneurial ventures. To date, however, little is known about the nature of the demand for equity crowdfunding or its impact on recipient firms. This paper draws on an interview-based study of entrepreneurs in 42 equity crowdfunded start-ups in the UK. The study found strong demand for this funding from these experimental and improvisational entrepreneurs within innovative, consumer-focused, early stage firms. Many entrepreneurs were classic "discouraged borrowers" attracted by the ability to obtain finance quickly with relatively little diminution of their equity or autonomy. In terms of impact, equity crowdfunding seems to confer important intangible benefits to investee companies which amount to more than money. Given their strongly improvisational nature, the concept of entrepreneurial bricolage seems a suitable theoretical lens explicating the behavioural aspects of the entrepreneurs examined.
\end{abstract}

$\begin{array}{llll}\text { Key Words: } & \text { Entrepreneurship } & \text { Start-ups } & \text { Crowdfunding } \\ & \text { Discouraged borrowers } & \text { Bricolage } & \text { UK }\end{array}$




\section{Introduction}

Finance for start-ups is crucial: a large body of literature attests to the perennial problems new and young firms encounter accessing finance (Berger and Udell, 1998; Cassar, 2004; Beck and Demirguc-Kunt, 2006). Informational opacity of new ventures, coupled with a limited lending track record, means many new and small firms frequently encounter acute difficulties accessing credit from mainstream lending institutions such as banks (Binks et al., 1992; Udell, 2015). These problems inhibit innovative new ventures from obtaining much-needed seed and startup capital (Colombo and Grilli, 2007), a problem accentuated by the recent global financial crisis (Cowling et al., 2012; Lee et al., 2015).

It comes as little surprise therefore, that considerable interest is now being shown in crowdfunding, which has emerged as a prominent new source of alternative entrepreneurial finance for innovative new ventures (Mollick, 2014; Lehner et al, 2015; Vismara, 2016a; Short et al, 2017). Due to advances in information and communication technology, crowdfunding enables many individuals to provide small amounts of finance to businesses via online crowdfunding platforms (Cumming and Vismara, 2017). In recent years, it has become firmly established as a key alternative financial instrument for new ventures (Moritz et al., 2015; Block et al, 2016), allowing entrepreneurs to tap the crowd instead of relying on banks or other specialised investors (Belleflamme et al., 2014). Accordingly, it "represents a potentially disruptive change in the way that new ventures are funded" (Mollick, 2014, p. 14), with the 
potential to radically transform the market for entrepreneurial finance (Cordova et al., 2015; Bellavitis et al, 2017).

Four main categories of crowdfunding exist: rewards, donation, lending and equity crowdfunding (Vulkan, et al, 2016). To date, research has focused upon the rewards-based model synonymous with the US firm Kickstarter and donation crowdfunding (Gerber et al, 2012; Colombo et al., 2015; Mollick, 2014; Giudici et al, 2017) ${ }^{1}$, however the concept has rapidly expanded both in terms of format and geography (Hemer, 2011; World Bank, 2013; Lin and Viswanathan, 2015; Short et al, 2017). In recent years increasing academic interest is being shown in equity crowdfunding - a prominent source of finance for nascent entrepreneurial ventures (Collins and Pierrakis, 2012; Ralcheva and Roosenboom, 2016; Vismara, 2016b; Block et al, 2016; Vulkan et al, 2016) originally rather narrowly defined as "a model in which crowdfunders receive a financial compensation" (Belleflamme et al., 2014, p. 317). Ahlers et al. (2015, p. 958) offer a more permissive definition of crowdfunding as "a method of financing, whereby an entrepreneur sells a specified amount of equity or bond-like shares in a company to a group of (small) investors through an open call for funding on Internet-based platforms". ${ }^{2}$ In contrast to this definition stressing the role of small or retail investors, it is important to note that crowd-investors encompass non-specialist, professional and institutionally based actors (Nesta, 2016; Wright et al, 2015b). Therefore, we propose the following definition of equity crowdfunding as "a funding process whereby entrepreneurs sell an equity stake in their venture

\footnotetext{
${ }^{1}$ In contrast, with a few exceptions (Lin and Viswanathan, 2015) researchers have tended to overlook debt-based or lending-crowdfunding models despite being the biggest part of the crowdfunding market (Bellavitis et al, 2017). ${ }^{2}$ This definition seems somewhat misleading because technically "bonds" are a form of long-term debt in which the issuing company promises to pay the principal amount at a specified end date. This form of repayment is more akin to the lending-based crowdfunding model (Atz and Bholat, 2016), whereas shares represent part ownership in a company.
} 
in return for investment from a disparate range of external investors, both large and small, mediated via online platforms".

Unlike rewards or donation models, which are largely deregulated, equity crowdfunding requires regulatory approval to operate and was thus, initially the smallest form of crowdfunding, comprising just 5\% of all crowdfunding investment by 2013 (Vulkan et al, 2016). It has quickly grown to become a major part of the crowdfunding landscape (Cordova et al., 2015; Nesta, 2016; Vismara, 2016a). The UK was one of the first countries to give regulatory approval and is now the most prominent market for equity crowdfunding both in terms number of offerings (i.e. 35) and size (Baeck et al., 2014; Signori and Vismara, 2016). Investment via these platforms leapt from a mere $f 3.9 \mathrm{~m}$ in 2012 to $£ 84 \mathrm{~m}$ in 2014 (Baeck et al., 2014), with the most recent market research undertaken by Nesta suggesting that this figure tripled to $\mathrm{f} 245 \mathrm{~m}$ in 2015 (Nesta, 2016). Equity crowdfunding is also quickly catching up with other forms of equity finance in terms of the number of deals closed each year. For example, it accounted for $18.5 \%$ of all visible equity deals and $32 \%$ of all visible seed-stage deals in the first half of 2014 (British Business Bank, 2014). Crowdcube, the UK's largest crowdfunding platform, alone has raised over $£ 100$ million on behalf of 290 ventures since its launch in 2011.

Of crucial importance in stimulating the growth of equity crowdfunding in the UK has been the role of tax incentives - the Seed Enterprise Investment Scheme (SEIS) and the Enterprise Investment Scheme (EIS) - originally designed to foster the business angel market in the UK (Wiltbank, 2009). The heavily deregulated and incentivised nature of its equity crowdfunding market means that the UK represents something of a unique 'laboratory' for this new form of 
entrepreneurial finance, differing from other geographic locations. It is thus a particularly interesting context in which to empirically explore the phenomenon of equity crowdfunding.

Despite its rapid growth, knowledge of equity crowdfunding in the UK is still in its infancy and its ability to "help firms grow beyond start-ups remains unclear" (Wright et al., 2015a, p. 7-8). As scholars begin to debate the merits of the crowdfunding concept more generally (Harrison, 2013), there is a need to further understand the "entrepreneurial cognition" (Fraser et al., 2015) underpinning this form of funding. Although a number of studies have examined the supply side of crowdfunding and motivations for investing in crowdfunding campaigns (Cholakova and Clarysse, 2015; Moritz et al., 2015; Kuppuswamy and Bayus, 2017), very little is known of what drives entrepreneurs to use crowdfunding generally (Belleflamme et al., 2013), let alone equity crowdfunding specifically (Ahlers et al., 2015). Scholars are also largely unaware of what effect(s) equity crowdfunding has on firm development and success (Moritz and Block, 2016), contributing to a lack of understanding of the effectiveness of disintermediated entrepreneurial finance (Cumming and Vismara, 2017).

This article makes an important contribution to the nascent crowdfunding literature. Empirically, the study found strong demand for this funding from improvisational entrepreneurs within innovative, consumer-focused, early stage firms many of whom were discouraged borrowers (Kon and Storey, 2003). In terms of impact, equity crowdfunding seems to confer important intangible benefits to investee companies which amount to "more than money", especially in terms of firm valuation, product validation and network augmentation. Theoretically, given the behavioural aspects of these entrepreneurs the concept of 
entrepreneurial bricolage (Baker and Nelson, 2005) seems a suitable theoretical lens for understanding the nature of start-ups during the crowdfunding process. These findings emanated from a large interview-based study of the demand-side of equity crowdfunded ventures in the UK ${ }^{3}$. The study examined the types of firms seeking equity crowdfunding, the rationale for seeking it, their experiences of the crowdfunding process and how the funding impacted their development. The study had three overarching and linked research questions:

RQ1: What is the nature of the demand for equity crowdfunding in the UK?

RQ2: What is the nature of the behavioural characteristics of entrepreneurs engaging with equity crowdfunding in the UK?

RQ3: What effect does this type of entrepreneurial financing have on recipient ventures?

These research questions are augmented by more specified questions derived from the crowdfunding and entrepreneurial bricolage literature. The article is structured as follows: the nascent literature on crowdfunding is reviewed, with sub-research questions highlighted. The research methodology and characteristics of respondent firms are then outlined, before empirical findings are presented and discussed with reference to the research questions posited. The article ends with conclusions and areas for further research.

\section{Literature Review}

To date, attempts at theoretical development within the emergent crowdfunding literature have been limited. Where theory has been deployed, it has typically been used to help

\footnotetext{
${ }^{3}$ To our knowledge the largest interview based study of crowdfunded recipients to date.
} 
understand the mechanisms and behaviour of the investors engaging in crowdfunding (Ahlers et al, 2015; Colombo et al., 2015; Kuppuswamy and Bayus, 2017), rather than to understand crowdfunding engagement from the perspective of the entrepreneur. There are a small number of exceptions examining the importance of social capital and networks on a firm's equity crowdfunding campaign (Vismara, 2016a; Brown et al, 2017). Owing to this lack of work examining the demand-side determinants of crowdfunding, the literature has typically ignored the nature of firms using equity crowdfunding, the behaviours and motivations of the entrepreneurs who engage with equity crowdfunding, and the specific benefits (or lack thereof) of this type of financing.

As the crowdfunding literature remains fragmented and theoretically underdeveloped, we draw on literature from entrepreneurial finance and entrepreneurial behavioural theories (most notably bricolage theory), to address the research questions underpinning our study and to derive related sub-research questions. We build on a considerable legacy of work regarding entrepreneurial finance (Drover et al, 2017). A deliberate attempt has also been made to draw upon the research gaps identified in the nascent crowdfunding literature (see Bruton et al., 2015; Moritz and Block, 2016; Pichler and Tezza, 2016; Short et al, 2017).

\subsection{The nature of demand for equity crowdfunding}

Scholars have theorised the preferences of how different forms of finance are viewed by entrepreneurs. For example, under the 'pecking order' theory, based on the loss of control associated with different types of finance (Myers and Majluf, 1984), firms are assumed to favour (in descending order of preference) internal funds, then bank lending and then equity 
sources of finance. This suggests that only after internal funds have been exhausted - the so called "3Fs" (founders, family and friends) - do firms approach external sources of funding. Firms tend first to approach banks for debt funding, however their lack of cash flow or collateral to borrow against (Berger and Udell, 1998; Carpenter and Petersen, 2002) and absence of a credit track record (Binks and Ennew, 1996) combined with the lending technologies utilised by banks (Berger and Black, 2011) means that they are often unable to access debt finance. This forces firms to seek out other means of raising capital, such as venture capital (VC) or business angel funding. That said, only an extremely select group of entrepreneurial firms are able to attract these forms of finance (Bellavitis et al, 2017, p. 5).

Temporal factors also affect the ability to obtain funding. The landscape facing SMEs has changed significantly in recent years, especially for small innovative firms, meaning the ability to attract both debt (Lee et al, 2015; Lee and Brown, 2016) and equity funding (Mason and Harrison, 2015) following the global financial crisis led to a breakage in the funding escalator for SMEs (North et al. 2013). This, undoubtedly, has opened up interest in other sources of alternative finance for SMEs (Bruton et al, 2015).

While the causal factors surrounding the emergence of crowdfunding seem fairly clear-cut, the drivers influencing entrepreneurs desire to utilise it are much less well understood (Ahlers et al., 2015; Frydrych et al., 2014), particularly with authors observing that there will likely be "considerable variation in the behaviour of entrepreneurs seeking different forms of this finance" (Bruton et al., 2015, p. 18). Additionally, the extent to which increased demand for crowdfunding is a function of the inability to access traditional sources of funding also remains 
unclear (Pichler and Tezza, 2016). Bruton et al. (2015) hypothesise that the demand for alternative funding may hinge on certain cognitive factors that shape entrepreneurial decisionmaking, particularly discouragement (Kon and Storey, 2003). This occurs when discouraged borrowers are deterred from applying for bank funding "because they feel they will be rejected" (Kon and Storey, 2003, p.7). These are an interesting but somewhat underresearched group of firm owners (Cowling et al, 2016) who have generally good investment opportunities but anticipate being declined by banks (Cole and Sokolyk, 2016). Research in the UK has estimated that while small in terms of the overall cohort of SMEs (i.e. $2.65 \%$ ) there are approximately 30,000 such firms (Cowling et al, 2016). Freel et al (2012) reported that there are twice as many discouraged borrowers as those who have actually had a loan rejected.

While discouragement is viewed as an efficient self-rationing mechanism amongst riskier firms (Han et al, 2009), it can have negative ramifications for the investment and employment growth (Ferrando and Mulier, 2015). Indeed, it is estimated that up to a third of discouraged borrowers would have been approved credit (Cole and Sokolyk, 2016). Further, it has been shown that younger firms led by experienced entrepreneurs display discouragement (Cowling et al, 2016). In other words, start-ups with the highest levels of informational opacity and lowest levels of collateral may be have the highest incidence of discouragement (Berger and Udell, 1998; Cassar, 2004). Of course, being discouraged from borrowing from banks does not, ceteris paribus, preclude the use of alternative external financing mechanisms. For example, anecdotal evidence suggests that equity crowdfunding appeals to entrepreneurs who feel unlikely to be able to access conventional forms of bank lending in order to grow (Collins and Pierrakis, 2012). Indeed, bad credit scores have been found to increase the probability of ventures seeking 
crowdfunding (Blaseg and Koetter, 2015). As conclusive empirical evidence on this relationship does not yet exist, however, our first sub-research question, linked to RQ1, is: to what extent are equity crowdfunded firms discouraged borrowers?

\subsection{The nature of the entrepreneurs engaging with equity crowdfunding}

To date, the crowdfunding literature has been focused on the supply side (i.e. the nature of investor behaviour) with little work helping us to understand the behaviours and characteristics of the entrepreneurs choosing to engage with equity crowdfunding. This focus has undoubtedly hindered our knowledge of what types of entrepreneurs experiment with alternative sources of finance. Within the wider entrepreneurship literature, traditional conceptions of new venture formation generally reflect a linear "design-then-execution framework" where "entrepreneurial volition leads to gestational and planning activities" (Baker et al, 2003 p. 256). By contrast alternative behavioural perspectives such as effectuation and entrepreneurial bricolage (Baker and Nelson, 2005) which describe how entrepreneurs undertake resource assembly, have become increasingly prominent (Fischer, 2012; Welter et al, 2016). Within these theoretical frameworks, under certain conditions "entrepreneurs take a different route to identifying and exploiting opportunities" (Fischer, 2012 p. 1019) which are less anticipatory or rational and more improvisational (Baker et al, 2003).

The concept of bricolage seems particularly germane to financially constrained start-ups. Indeed, the most crucial assumption underlying bricolage is resource scarcity (Welter et al, 2016) and, given that most start-ups are notoriously resource constrained, bricolage seems particularly pertinent to understanding their financial evolution (Fischer, 2012). Bricolage 
behaviours are commonly associated with making do with what is at hand, creating something from nothing and experimenting by combining resources for new purposes (Fisher, 2012). Often linked to the concept of resourcefulness (Baker, 2007), bricolage theory presents "a forum in which organizational improvisation, creativity, social skills, combinative capabilities, and other characteristics are called into play" (Baker and Nelson, 2005, p. 361). Entrepreneurs who exhibit such a mind-set view resource limitations as both as problems and opportunities (Welter et al, 2016).

Given its potential theoretical relevance, surprisingly, little empirical work has applied bricolage theory within an entrepreneurial finance context, despite recognition that newer forms of entrepreneurial finance, such as crowdfunding, seem particularly pertinent to experimental

entrepreneurs (Lehner, 2013). From this line of reasoning we derive the following supplementary question, linked to RQ2: do the behavioural characteristics of entrepreneurs engaging in equity crowdfunding resonate with entrepreneurial bricolage?

\subsection{The effect of equity crowdfunding on recipient ventures}

A number of studies on equity crowdfunding are beginning to explore some of the additional benefits this form of finance confers on its recipients. So for example, some early observers felt that crowdfunding could provide the 'wisdom' of the crowds (Surowiecki, 2004) and more recent work notes that individuals from diverse backgrounds "bring various pools of local knowledge together" (Collins and Pierrakis, 2012, p. 25). Indeed, there is an emergent body of literature which identifies various benefits arising from crowdfunding (Belleflamme et al., 2014; 
Lehner et al., 2015), including public exposure and validation from customers. In this sense, "crowdfunding can be used as a promotion device, as a means to support mass customization or user-based innovation" (Belleflamme et al., 2014, p. 602). Indeed, a recent study of US crowdfunded projects discovered that the number of backers involved in a campaign positively influences the subsequent performance of the recipient firm products, leading the authors to conclude that non-financial benefits that accrue from attracting numerous backers, or early innovation adopters, is where much of the value of crowdfunding resides (Stanko and Henard, 2017, p. 794).

While there seems some emerging evidence of positive benefits from crowdfunding, this issue remains relatively under-researched at present, especially in relation to equity crowdfunding. Whereas a sizeable literature exists surrounding the value added contributions that VCs and business angels make to investee companies (Hellmann and Puri, 2002; Politis, 2008), there is little evidence that these benefits accrue from equity crowdfunding (Macht and Weatherston, 2014). VCs can scout for, and screen firms, to ensure they select those with strong growth potential (Baum and Silverman, 2004). Additionally, VCs can add value to firms through an interactive relational form of upskilling the managerial competencies within the firms (Hellman and Puri, 2002) which leads some to label VCs as 'smart money' to depict this process (Sørensen, 2007). By contrast, due to their lack of experience some note that "crowds are frequently stupid" (Isenberg, 2012, p. 4) hence, their non-financial contribution to a firm might be limited. Therefore, the final research question, linked to RQ3, is: what tangible and nontangible benefits do firms obtain from equity crowdfunding? 


\section{Methods and Cohort Characteristics}

Reflecting the dominant trend within entrepreneurship research (Suddaby et al., 2015), most crowdfunding research has been quantitative (see for example, Belleflamme et al., 2014; Cholakova and Clarysse, 2015; Colombo et al., 2015; Mollick, 2014), with very few studies adopting a qualitative approach (see for example, Lehner et al., 2015; Schweinbacher and Larralde, 2012; Moritz et al., 2015). As other scholars have noted, it is important to move crowdfunding research into more qualitative research methods to provide deeper understanding of specific "entrepreneurial activities and processes" (Frydrych et al., 2014, p. 263). This kind of exploratory inductive research can help elicit strong empirical insights, whilst opening up the opportunity for theoretical development (Eisenhardt, 1989; Graebner et al., 2012). With a view to contributing to this gap, this study draws on in-depth qualitative interviews with 42 UK-based entrepreneurs who successfully obtained equity crowdfunding to explore how and why entrepreneurs engage in crowdfunding.

\subsection{Data Collection}

Our sample was identified purposively via the three main equity crowdfunding platforms in the UK - Crowdcube, Seedrs and SyndicateRoom ${ }^{4}$. To be eligible for inclusion, ventures were required to (a) have successfully completed their funding campaigns between January 2011 and January 2015 and (b) to have raised at least their target amount. Based on these two criteria, from the three platforms we identified 156 eligible firms based on the above criteria. Through a snowball approach, a small number of other firms $(n=4)$ who had raised crowdfunding through

\footnotetext{
${ }^{4}$ Company information is publicly available via Crowdcube, Seedrs and Syndicate Room for the majority of firms that have successfully raised crowdfunding, but not all.
} 
two other UK-based equity platforms (Shareln and Crowdbank) were also identified. Of these 160 firms -all of which were initially contacted by both telephone and email at the end of January 2015 - 42 agreed to participate, giving a response rate of $26 \%$. It is important to note that the success rate for raising equity finance on crowdfunding platforms is relatively low, with only around $40 \%$ of firms successfully completing the funding process (Financial Times, 2015). Thus the entrepreneurs interviewed should be considered atypical rather than representative of all those who attempt and begin the equity crowdfunding process.

Interviews with the 42 entrepreneurs were undertaken between February and June 2015 by three of the researchers. The interviews were semi-structured, conducted either by telephone or Skype with the founder/entrepreneur, and were on average 45 minutes in length. They were recorded and transcribed immediately upon completion. The interviews covered a number of range of thematic topics linked to our overarching and sub-research questions, including levels of "discouragement", rationale for seeking crowfunding, benefits (expected or unintended), disadvantages and impact. As more than one researcher conducted the interviews, a standard interview template was utilised, with standardise probes for each question. Close attention was paid to ensure that each researcher adopted the same interview protocol.

To triangulate the interviews with entrepreneurs, a small number of interviews were also conducted with eight other actors in the equity crowdfunding market to better understand emerging themes and develop a more holistic understanding of the entire crowdfunding process and the wider crowdfunding ecosystem. Supplementary interviews with related actors are often used in qualitative research to help triangulate emerging themes from company 
interviews (Patton, 2002). These individuals included business angels who had co-invested through crowdfunding platforms $(n=2)$, equity crowdfunding platforms themselves $(n=3)$, intermediaries (lawyers, accountants) $(n=2)$ and a specialist crowdfunding consultant $(n=1)$. No quotations from these triangulation interviews are included in this paper, although these interviews played a role in overall data analysis.

\subsection{Data Analysis}

The overall aim of the research was to develop "bottom-up" theories grounded in the real world to ensure the work "remained authentic and identifiable" to the entrepreneurs interviewed (Cope, 2005, p. 174). Therefore, the main form of data analysis utilised a predominantly grounded approach using the Gioia methodology, whereby data-to-theory connections were prioritised (Gioia et al., 2013). It was partially grounded in that some of the issues within the study emerged inductively from the data through a process of "concept discovery" which is the strategic process of moving from data to abstract categories (Martin and Turner, 1986) while other issues arose from our reading and understanding of the relevant literature (i.e. discouragement) ${ }^{5}$. The interpretive approach adopted aimed to preserve the subjective and interpretive nature of the data analysis process (Leitch et al, 2010; Graebner et al., 2012).

As often occurs with interpretive work, part of the informal analysis began during the interview phase (Gioia et al, 2013). The formal data analysis began with the three researchers involved in data collection independently mapping the first order concepts elicited from each of the 42

\footnotetext{
${ }^{5}$ Strictly speaking, under a grounded theory approach the researcher should not be committed to pre-existing theory when entering the research site (Parker and Roffey, 1997).
} 
interviews, which produced a long list of theoretical concepts. In line with others, this involved examining each interview separately to see what was common and what was specific to each specific case (Cope, 2005). These were then explored for similarities and differences, leading to identification of a number of core second order themes through a process of "axial coding" to reduce the themes to a manageable number (Charmaz, 2014). Coding involved the use of labels derived directly from the informant interviewees (i.e. "more than money"). Clearly, qualitative data can be interpreted differently by different researchers. To enhance inter-coding reliability each transcript was analysed independently by all three researchers involved in data collection, before codes were compared and reassessed by the researchers as a group in order to ensure analytical rigour (Guba and Lincoln, 1994). Discussions between the researchers formed a central part of the coding process. As second order themes emerged, the research transitioned from an "inductive" to an "abductive" approach (Dubois and Gadde, 2002), whereby our data and existing theory were considered side by side (Gioia et al., 2013).

Given the small number of equity crowdfunded companies in the UK, the publicly available information on successful campaigns and the associated risk of identification, all interviewees were guaranteed anonymity rather than confidentiality. Direct quotations have been used to ensure transparency of collected data (Healy and Perry, 2000), however company names and crowdfunding platforms have been anonymised at the request of participants and no specific identifiers (e.g. sector, location) have been ascribed to individual respondents. The direct quotations included in this paper are taken from a representative cross-section of two-thirds of the 42 companies interviewed and, where multiple quotes are used to demonstrated key 
themes, these are taken from different interviewees. No more than one extended quotation has been used from each interviewee.

\subsection{Cohort Characteristics}

The vast majority (90\%) of entrepreneurs who had raised finance were male, predominantly in the 25-45 age range, nearly all of whom (90\%) had significant previous entrepreneurial experience of either establishing or working in start-ups. All 42 of the entrepreneurs interviewed exhibited the classic attitudes and behaviours of growth oriented entrepreneurs (see Mason and Brown, 2013), noting an appreciation of risk, high levels of entrepreneurial ambition, and the desire to grow their business (in both turnover and profitability).

The majority of businesses (57\%) were early stage aged between one to three years (see Figure 1). This suggests that it is primarily start-ups who are active in raising equity crowdfunding. However, due to the presence of some more established firms $(n=10)$, the average firm age in our sample was four years.

Insert Figure 1 here

Very few of the companies in the sample (10\%) conformed to the traditional view of a "high tech' venture with a high level of Research and Development (R\&D) activity. Most were operating in the $\mathrm{B} 2 \mathrm{C}$ markets focusing on consumer products and services, operating in a wide range of industrial sectors (see Figure 2), the most common being Food and Drink (26\%), Digital Media (17\%) and Clean Tech (12\%).

Insert Figure 2 here 
The firms had a distinctive geography (see Figure 3). Half of the sample (50\%) were located in London, while other small pockets were in Bristol (8\%) and Edinburgh (5\%); the remaining firms were scattered around the country, including the South West, the Midlands, the North of England and the central belt of Scotland. These patterns strongly reflects other previous research on the uneven geography of crowdfunding in the UK (Baeck et al, 2014; Langley and Leyshon, 2017). To some degree these spatial patterns partly mirror the main sources of startups within the UK economy. Given the fact that half the population of the sample originated from London may suggest that access to - and engagement with - crowdfunding may be subject to the same spatial inequities exhibited by venture capital and business angels investments (Martin et al., 2005; British Business Bank, 2017) ${ }^{6}$.

\section{Insert Figure 3 here}

In the main, the entrepreneurs were looking for start-up and growth capital to develop their businesses. Just under half of the firms (48\%) raised between f100k and f199k (see Figure 4). The average amount raised by firms in our sample was $£ 408,484$, while the median value was $£ 150,785$. The average amount raised was double that identified by Nesta (£199k) for the 20122014 period (Baeck et al., 2014), suggesting that deal size is increasing. Five companies interviewed raised over f1million. Excluding these firms from the analysis, the average amount raised drops to $£ 237,339$, still above the Nesta figure (Baeck et al, 2014). To raise this investment, firms issued between $5.81 \%$ and $32.17 \%$ equity (on average $18.95 \%$ ) to between 3

\footnotetext{
${ }^{6}$ Other research notes the "home bias" of investors in other types of crowdfunding markets (Lin and Viswanathan, 2015).
} 
and 966 individual investors (on average 165). ${ }^{7}$ While it was not always possible to know the exact composition of investors within the crowdfunded rounds, business angels were known to be involved in 30 (71\%) of the ventures examined.

\section{Insert Figure 4 here}

The majority of the crowdfunded firms interviewed were in receipt of the tax incentives highlighted earlier ${ }^{8}$. An individual taxpayer can claim $30 \%$ tax relief on up to $f 1 \mathrm{~m}$ of investment per tax year under the EIS scheme whereas this figure is higher (i.e. 50\%) under the SEIS (i.e. $£ 100,000$ of investment per tax year). Typically, the entrepreneurs raising SEIS eligible relief raised smaller amounts, meaning they tended to be particularly early-stage; more often than not pre-revenue de novo start-ups. These are riskier investments and, as such, the tax relief is more generous under SEIS. On the other hand, firms who raised under the EIS scheme tended to be more mature, raising larger sums and are mainly revenue generating or have a larger user/customer base.

\section{Findings}

The findings are structured around the three overarching research questions: (1) the nature of demand for equity crowdfunding; (2) the behavioural nature of the entrepreneurs engaging with equity crowdfunding; and (3) the effect of equity crowdfunding on recipient ventures.

\subsection{The nature of demand for equity crowdfunding}

\footnotetext{
${ }^{7}$ These figures exclude firms that raised finance using the Seedrs platform $(n=13)$, which has a nominee structure where all investments are managed by a single nominee.

${ }^{8} \mathrm{~A}$ precise figure cannot be given owing to the incomplete information on all the companies.
} 
The entrepreneurs interviewed articulated a number of factors that had influenced their interest in, and ultimately use of, equity crowdfunding as a source of entrepreneurial finance. An important consideration for the majority (70\%) was the perceived lack of other financing alternatives available. As the majority of these firms (57\%) were early stage ventures, they often lacked collateral and assets, as well as a proven financial track record. These 'liabilities of newness' (Stinchcombe, 1965) resulted in many entrepreneurs thinking that they were unlikely to be able to obtain debt funding from banks (62\%) or equity funding from venture capital (40\%) and business angels (45\%).

Addressing sub RQ1, the vast majority of the interviewees could be classed as classic "discouraged borrowers" who were deterred from applying for bank funding because they felt they would be rejected". One entrepreneur stated that "banks are a bad source of finance for early stage ventures" while another bluntly stated: "banks would never come near me". Few (25\%) had considered approaching their bank or other financial institutions, let alone had made an approach (15\%). No one reported being turned down by a financial institution. The entrepreneurs interviewed were therefore discouraged (Kon and Storey, 2003) rather than declined borrowers. ${ }^{10}$ The general feeling amongst respondents was that it is currently easier to get money "from the crowd than from the bank", particularly if firms are selling a product or service that resonates with the general public. The common view appeared to be that individuals tend to buy into concepts and thus growth potential, whereas financial institutions tend to be more interested in a financial track record to mitigate lending risks.

\footnotetext{
${ }^{9} \mathrm{~A}$ precise figure cannot be given because some of the entrepreneurs explained their borrowing behaviours in such ways which prevented a straightforward categorisation.

${ }^{10}$ While the term 'discouraged borrowers' (Kon \& Storey, 2003) is normally associated with bank debt finance, potentially it could be extended other forms of funding such as VC and business angels etc.
} 
"We didn't even look in to [a bank loan]. We felt banks would not fund us for the amount we needed and the limited experience we had under our belts."

"No one trusts banks anymore and they aren't happy to lend. If I'd gone to the bank seeking a personal loan of $f 70,000$, not that that would necessarily have been possible, I'm then straddled with a rather large payment that I have to satisfy every month as well. So, for me, giving away $16 \%$ of equity is a no brainer."

The entrepreneurs also indicated that, due to difficulties identifying business angels, they were keen to pursue crowdfunding as an alternative source of equity financing. Although, as noted earlier, in many cases angels and the crowd were not mutually exclusive, with $71 \%$ of the ventures in our sample identifying business angels within their cohort of investors. The focus of nearly all the firms interviewed $(93 \%)$ was to raise 'growth capital' through equity crowdfunding, which they felt they could do without losing either significant equity to investors or entering into a long repayment process with the banks.

"It filled a gap - good way of getting angels together as well as friends and family. Great advantage over control, you name the price yourself - it's not a negotiation."

Although interviewees considered crowdfunding to be a critical mechanism for raising earlystage growth capital, they all regarded it as only one part of a wider funding strategy. The entrepreneurs were therefore not looking to replace other sources of financing with crowdfunding, but rather sought to augment other debt and equity instruments as "part of [their] wider funding strategy" to best serve their interests. The majority of respondents (70\%) noted that, whilst crowdfunding is particularly relevant to them at this point in time, they will 
look to other sources of finance in the future and will adjust their funding strategies accordingly. This shows the experimental "bricoleur" nature of the way in which entrepreneurs approach crowdfunding.

A final issue that seemed central to the heightening appeal of crowdfunding concerned the tax incentives on offer in the UK. In the majority of cases the entrepreneurs acknowledged the important role of the SEIS and EIS schemes in attracting investment.

"It's pivotal. I've founded two other medical device companies. I use EIS to attract potential investors: it's key; it's vital. It's brought investors to the table that normally wouldn't be there."

"We applied for the SEIS scheme - it's a great scheme and we were very happy to get that assurance. I certainly think it would be a huge motivator in a lot of people's decisions [to use equity crowdfunding]."

\subsection{The behavioural nature of the entrepreneurs engaging with equity crowdfunding}

In the main, the entrepreneurs interviewed were all well-informed individuals, with the majority (83\%) actively tracking and reading up on crowdfunding in advance of utilising this funding mechanism for their own ventures. They could be considered 'early adopters' of both the crowdfunding concept and of its use as a source of alternative entrepreneurial finance. Despite their knowledge, however, not all entrepreneurs were successful with their initial approaches to crowdfunding platforms. Two entrepreneurs in our sample were rejected on their first approach to a platform due to a perceived lack of fit with the platform's investor 
profile in one case and disagreements over the company valuation as well as doubts about the firm's potential to meet the fundraising target in the other ${ }^{11}$.

For approximately half of the entrepreneurs (48\%) interviewed, engaging with an equity crowdfunding platform was an ad hoc rather than planned 'event', often influenced by peer-topeer interactions and word of mouth referrals from friends, family and business contacts. For the other half (43\%), it was more of a planned and closely evaluated process, whereby financing options (and their pros and cons) had been critically appraised, with crowdfunding deemed to be the most appropriate funding mechanism. In a minority of cases (9\%), crowdfunding was a 'last resort' for firms that needed funding as soon as possible and had no alternatives to pursue. The predominantly ad hoc semi-planned nature of the use of crowdfunding illustrates the creative and improvisational nature of the entrepreneurs examined.

"We got fed up; let's concentrate on growing the business instead of trying to find money. We decided the economy's easing; let's try this new route of crowdfunding"

A critical factor driving many of these entrepreneurs desire to turn to equity crowdfunding were temporal issues. Timing factors such as the relative speed in which the entrepreneurs could raise and obtain this form of finance were deemed critical to its appeal. In comparison to bank lending and other forms of equity finance, crowdfunding was seen as much quicker and easier option: "time frame - we wanted to know when we would be funded by". In examining funding options, one highly experienced founder stated he'd "met so many time wasters - it's

\footnotetext{
${ }^{11}$ Respondents from Crowdcube and Seedrs noted that only 1 in 5 applications to their platforms are accepted.
} 
just exhausting". Others highlighted the fact that pinpointing appropriate business angels was very time-consuming in comparison: "it puts a time limit on fundraising".

Unquestionably, the biggest single advantage associated with crowdfunding was the speed at which a round of crowdfunding can be completed, in comparison with other sources of financing. The average length of time taken by the entrepreneurs in our sample to raise financing via crowdfunding varied from nine days to over four months, with many entrepreneurs noting their surprise at how quickly the process was completed. ${ }^{12}$ The speed of raising funding meant that "distractions were minimised", allowing firms to "get back into action" quickly. Indeed, the majority of entrepreneurs were quick to identify the importance of speed when raising finance for early stage businesses, as drawn-out discussions with potential investors can hinder the day-to-day management of operations and put at risk the sustainability and growth of a new venture.

"Crowdfunding is probably quicker than VCs or angel investors."

"[Angels and VCs] are slow, they drag their feet."

The desire to quickly obtain the funding suggests that the entrepreneurs were "happy to experiment" with this newer form of finance. Many of the behavioural traits confirm a strong element of entrepreneurial bricolage within these extemporizing entrepreneurs. Plus, many of these entrepreneurs saw a combinative logic to this form of finance:

\footnotetext{
${ }^{12}$ Note that many entrepreneurs did not include the amount of time spent on preparatory work (e.g. developing a business plan; obtaining initial investment from the angel community) in their conception of the length of the crowdfunding process. In reality, the process was often more lengthy than respondents acknowledged.
} 
"We needed the money quickly, we had seen how well others had done and we wanted to, not only generate money, but also to attract investors that might become ambassadors".

\subsection{The effect of equity crowdfunding on recipient ventures}

\section{Benefits of Equity Crowdfunding}

Respondents also noted that crowdfunding offered non-financial benefits in terms of concept validation and company valuation. Given the early-stage nature of the majority of companies in the sample, achieving proof-of-concept and product/service validation were of particular concern. Half (50\%) emphasised that they hoped obtaining funding from the crowd would validate and endorse their core offering and their business model generally. They also hoped that they would build a pipeline of potential customers in the process. Additionally, around half of the firms in our sample - particularly those that had very recently started trading and those that had grown rapidly - sought to use the crowdfunding process to put a value on their company as the entrepreneurs were unsure of its market value.

"Crowdfunding had a useful purpose in pinning down the value of the business and that's what it did - it pinned down the value of the company at a level that we worked with."

"It was [name of platform removed] who valued the company at a certain value which was great for me and people were willing to offer investments for essentially something that didn't really exist yet. So, in a way, it was sort of 'free money."' 
A number of entrepreneurs reported that the crowdfunding process gave them a more favourable valuation than they would have had from VCs or business angels. Others highlighted the importance of retaining their autonomy and control of their business by having a dispersed ownership structure rather than having a single dominant shareholder.

"We did do a little more angel hunting before deciding to crowdfund, but tended to find that in general both angels and venture capital firms were asking for larger equity stakes than we were prepared to give."

"When you have lots of small investors and you're an early stage company...it means you can maintain a lot of autonomy"

Finally, respondents were keen to stress the importance of having external investors. The majority explicitly emphasised the benefit of being held accountable to those with a stake in the business, noting that this provided a set of checks and balances to ensure the performance of the business was externally monitored. This perceived accountability to investors was consistent regardless of the type of investor (professional or 'one of the crowd') and the amount invested. As one entrepreneur commented:

"We feel that equity makes you more accountable, it makes you more responsible, it makes you work harder."

The entrepreneurs in the sample were genuinely appreciative of having a "critical mass" of supporters, offering not just financial support but also potentially other forms of assistance as required. Factors such as media exposure, interaction with new shareholders, end-user engagement and feedback were all important intangible "network-related" benefits that firms 
received from this type of funding. Indeed, investors in crowdfunding often become quite vocal advocates of these firms ${ }^{13}$. In turn, entrepreneurs use these new networks to gain media exposure for their venture and to receive customer feedback on product development. For example, one company used their investors to test out their new range of craft beer products to help inform their new product development.

"You have an audience who are willing you on - they want to see you succeed and they have a vested interest in you being a success."

The network related benefits also appear to evolve over time. What seems to characterise this process is a transition away from personal strong ties, which in turn fosters engagement in wider business networks predicated on weak ties. Strong ties act as a conduit towards developing a range of weaker ties across a wider set of business networks. The desire to develop and "harden" these weak ties is perhaps the most fluid and dynamic aspect at the end of the crowdfunding process.

"Some of the biggest investors who came to us through [Platform] are proving to be invaluable to our business due to their skills and networks"

"[Crowdfunding] has allowed us to become involved with investors we hadn't met before - to start building new relationships."

\section{Disadvantages of Equity Crowdfunding}

Respondents noted that crowdfunding also has its disadvantages. A significant minority of entrepreneurs reported that it entailed a significant administrative burden, including liaising

${ }^{13}$ The term "fanvestors" is sometimes used to depict the pro-social behaviours of these types of investors. 
with the crowdfunding platform, meeting the requirements for government investment schemes (e.g. EIS/SEIS), responding to requests for business plans and other company information from potential investors and, upon receipt of funding, responding to queries from a multitude of investors.

"[Your investors] have all put in a chunk of equity. If you're spending half your time keeping them happy then that's a problem, not a benefit."

Many entrepreneurs noted that queries from investors had taken up significantly more time than they had anticipated, in over half of the cases this was between 100-200 hours. In some cases, particularly in more technical B2B concepts, this was due to the fact that investors had a limited understanding of the nature of the business and its product/service offering and thus required significant "education" about the business. In other cases it was simply a challenge to manage a multitude of small investors, all of whom had different interests, queries, motivations and investment knowledge. This was particularly the case for just over a third of the firms that added over 100 new investors. As one of these entrepreneurs explained:

"Dealing with 120+ investors individually can be a nightmare! The structure with, say, 120 individual investors can also put off future investors such as VCs just due to the admin involved."

Although largely considered a benefit, valuation was, for a minority of businesses, considered to be a potential drawback of crowdfunding. A number of entrepreneurs noted that they struggled to come to a fair valuation of their business with the crowdfunding platform, only to have to subsequently revise this valuation in order to generate interest from the crowd. 
"We hit a wall about 5/6 weeks in when investment dried up. So we made the decision to reduce the valuation of the company. In came some heavy hitters and the whole thing was over in a week."

A further potential disadvantage of crowdfunding is the reputational risk (and potentially longer-term viability) to the business should it be unable to raise its minimum target funding. A small number of entrepreneurs commented that they were under significant pressure to meet their fund-raising threshold, because failure to do so would have a negative impact on public perception of the business and influence the possibility of raising future finance through followon rounds of crowdfunding or other entrepreneurial finance. Although crowdfunding was recognised to offer enhanced visibility compared with raising investment from business angels and VCs, this visibility could also have a downside.

A final disadvantage identified by entrepreneurs was the issue of access to further rounds of finance. The overwhelming majority of respondents noted that crowdfunding provided short term limited finance and that, over time, this mechanism would become simply one part of their overarching financing strategy.

"We would consider using it again, but we'd think carefully if it was the right approach. Many investors are lacking business experience and this could be difficult for us - we're not only looking for the money."

A number of entrepreneurs expressed concern over how easy it would be to undertake repeat rounds of crowdfunding, particularly once the business has scaled, noting that at that point it might be less efficient and straightforward compared with taking out a bank loan or standing 
line of credit. Very few were expecting to undertake further rounds of crowdfunding, with the majority expressing hesitation about its appropriateness as their companies expanded.

"We won't be using [crowdfunding] again. We'll be looking to raise a lot more next time around and I don't think that the crowd will be the best source."

\section{Impact of Equity Crowdfunding}

Reflections by the entrepreneurs on the impact of the crowdfunding process, while varied, highlighted a number of key benefits. First, respondents noted that engaging in crowdfunding resulted in "more than money". Nearly all respondents acknowledged that various intangible benefits arose from the crowdfunding process, specifically in terms of accessing new customers, gaining media and press attention to supplement their other marketing activities, validation of their product/service offering and development of their business model. These benefits, while not themselves financial, have the potential to financially benefit firms as they develop and grow and are linked to the 'affinity' created between investors and firms.

"We found it extremely useful just from the amount of people who want to support us and the amount of opportunities it has opened up just off the back of getting mass marketing exposure."

"The feedback from the advertising and the publicity of it were all beneficial to the company as a whole, not just the finance."

Second, by raising capital, firms were able to take on new employees. A number of entrepreneurs (17\%) stressed just how important job creation was in order to adequately scale up their businesses, with significant proportions of the funding they raised earmarked 
specifically for salary costs. Not all firms could articulate the precise number of new jobs they intended to create, but many anticipated growing from around micro firms with between 5-10 employees to around 20-30 employees in the next six months. Respondents did note, however, that these new jobs would not be sustained through the money raised via crowdfunding and that other sources of income would be needed to maintain employment and create new jobs in the future. According to one firm, who planned to double their employees from 20 to 40 , the funding only bought them "around 6 months", after which time other sources of funding would be needed to sustain their growth. Another entrepreneur noted:

"We already burned [through the money] very quickly. We need more because we didn't raise enough money to hire sales people."

The final theme identified concerned access to follow-on funding. The majority of the entrepreneurs felt that having had a successful crowdfunding campaign enabled them to attract the attention and interest of business angels and VCs and also "opened doors" to other forms of future equity financing.

"We're on the radar of the [VC] community now, so I think we have more options than we did in terms of next-stage funding."

Indeed, a considerable number of entrepreneurs noted that the experience would be "useful in future funding rounds". They also observed that successful fundraising might have beneficial implications for accessing other sources of finance in the future such as private equity and, in some cases, grant funding, whereby a track record of obtaining other forms of finance can be seen as beneficial. 


\section{Discussion}

In order to highlight our key empirical findings, we return to the key research questions posited. In terms of the nature of demand for equity crowdfunding in the UK (RQ1), the perceived lack of financial alternatives was a key rationale for entrepreneurs to seek equity crowdfunding. This corroborates speculation that "discouraged borrowers may turn to newer forms of alternative as the only option left available to them" (Bruton et al., 2015, p. 18). While this is an unambiguous finding, it is important to note that demand is influenced by several other factors, of which speed is particularly critical. Quite often the speed in which firms could obtain finance was a crucial factor prompting them to pursue this form of equity funding. This links to the strong bias for action within these entrepreneurs. The organisational legitimacy crowdfunding confers on firms also seems important (Frydrych et al., 2014), particularly in the context of the early stage ventures in this study.

In accordance with the pecking order theory (Myers and Majluf, 1984), the majority of the interviewees pursued crowdfunding to minimise the dilution of their equity stakes and to retain maximum levels of autonomy. Interestingly, while some entrepreneurs appreciated the lack of interference from investors, most welcomed greater levels of scrutiny. The benefits of an external 'control mechanism' is in line with resource dependency theory (Street and Cameron, 2007) and has been noted in other forms of equity finance such as VC (Hillman and Dalziel, 2003; Wijbengaet al., 2007). In certain respects, crowdfunding seems to be creating a 'diluted' form of equity funding with less prohibitive limitations to entrepreneurial autonomy than other forms of equity funding. By contrast, VC-backed firms often adopt strong monitoring and control procedures such as the use of contractual clauses (Kaplan and Strömberg, 2003). The 
preference for equity crowdfunding over other forms of equity funding is therefore, consistent with the pecking order theory.

With regard to the nature of the entrepreneurs engaging with equity crowdfunding in the UK (RQ2), a key feature of the entrepreneurs interviewed was their willingness to innovate and experiment. These entrepreneurs were very proficient at bundling financial resources from a variety of different sources - friends, family, business angels and the crowd - to help alleviate and overcome their internal resource constraints. The often ad hoc and unplanned nature of these extemporizing entrepreneurs showed them to be very creative, spontaneous and improvisational. Such actions strongly resemble the behaviours associated with entrepreneurial bricolage outlined earlier (Baker et al., 2003; Baker and Nelson, 2005). In line with bricolage theory, the entrepreneurs examined had a very strong bias for action and a refusal to enact resource constraints (Baker and Nelson, 2005), particularly given the penurious lending environments facing these start-ups following the financial crisis. For example, some firms sold ideas and early concepts to investors before a tangible business existed - literally "creating something from nothing"14. Given the reported findings, the bricolage concept seems a suitable theoretical lens for understanding the behavioural aspects of the crowdfunding process.

Our empirical findings also demonstrate the important role both interpersonal and interorganisational networks play in mediating the equity crowdfunding process for start-ups. Strong social and relational skills are linked to bricolage (Baker and Nelson, 2005). While

\footnotetext{
${ }^{14}$ Indeed, one entrepreneur used rewards-based crowdfunding to test the market for his product and generate demand. This 'order book' was then used to secure further equity crowdfunding.
} 
crowdfunding networks help start-ups access funding, they also stimulate and provide a conduit for wider boundary spanning interactions with a multiplexity of different ties, both strong and weak. The network related benefits also appear to evolve over time, highlighting the need for a processual perspective when examining crowdfunding (Hjorth et al, 2015; Brown et al, 2017). Emphasising the importance of social capital during the equity crowdfunding process (Vismara, 2016a), both personal and business networks were extensively utilised by entrepreneurs. Drawing on personal networks enabled the nascent firms to augment their own internal resource endowments by tapping the so-called "three Fs". The recombination of resources was evident in the way entrepreneurs repacked existing funds and investors to help build campaign momentum, which in turn drew in the crowd. The early adopters examined during this study also seemed adept at drawing on business networks in the form of the embryonic 'crowdfunding ecosystem' - comprising accelerators, incubators, crowdfunding platforms, crowdfunding consultants and business angel investors. ${ }^{15}$ These network effects mark equity crowdfunding out as a distinctively "relational" form of entrepreneurial finance, drawing heavily on both strong pre-existing and new weaker ties on a variety of dimensions. Arguably, poorly connected entrepreneurs may not have sufficient networks or social capital to undertake crowdfunding effectively.

Our final research question (RQ3) explored the effect that equity crowdfunding has on recipient ventures. In line with others, the data reveals both tangible and intangible benefits from interacting with crowd investors (Belleflamme et al., 2014; Lehner et al., 2015; Stanko and

\footnotetext{
${ }^{15}$ Interestingly, a number of the firms had obtained initial seed funding via accelerators and incubators prior to undertaking crowdfunding.
} 
Henard, 2017). This included media exposure, interaction with new shareholders, end-user engagement and feedback were important intangible benefits that firms received from this type of funding. Indeed, in one isolated instance one entrepreneur noted that they engaged in equity crowdfunding primarily was to obtain these benefits, claiming they "didn't really need the money". This reinforces the conclusion that by working the crowd, important entrepreneurial learning can occur (Belleflamme et al., 2014; Gerber and Hui, 2013; Ordanini et al., 2011). Additionally, successfully raising crowdfunding can act as a signal of quality to uninformed third parties (Vismara, 2016), hence affirming the new venture's legitimacy which could in turn further facilitate future investment (Hsu, 2004; Plummer et al, 2016).

There are important practical implications arising from the study regarding the substantive inter-platform heterogeneity detected ${ }^{16}$. Given the relatively modest sample we cannot offer concrete conclusions on this front but two observations can be made. First, it appears that angel-led platforms such as Syndicate Room, who require that the deal has a sizeable backing from an existing professional investors, tend to fund more traditional VC and angel-backed technology-based companies with large scale investments. By contrast, Crowdcube typically funds younger consumer-focused start-ups with smaller levels of capital. Second, another byproduct of inter-platform differences is the differentiated nature of shareholder interactions. While Seedrs adopt a unified nominee structure to represent investors, in some platforms such as Crowdcube shareholder management is the sole responsibility of the start-up themselves. The findings reported that shareholder management was extremely difficult for some of these smaller companies given the magnitude of new investor relationships. Within the Crowdcube

\footnotetext{
${ }^{16}$ We are grateful to one of the referees for probing the authors to consider these cross-platform issues.
} 
model interacting with large numbers of shareholders can yield benefits in terms of follow-on investment and network augmentation, it can also be extremely time-consuming for early stage businesses. Clearly, entrepreneurs need to closely examine the differential nature of these arrangements before selecting the most suitable platform partner.

Finally, the work also has important policy implications. In essence, tax incentives matter and seem to play a pivotal role in fostering this source of finance in the UK. Corroborating other work examining crowdfunding in the UK (Signori and Vismara, 2016), the tax incentives examined seem to play a strong role in helping firms raise additional capital. They also seem to be propagating this form of investment within the investment community. Given the positive effects induced by the UK's fiscal incentives, careful consideration in other countries should be paid to the design of appropriate policy instruments. That said, given the important role played by professional investors in the process, fiscal incentives may not work well in countries lacking a culture of professional angel equity investors.

\section{Conclusions}

In light of this assessment, equity crowdfunding appears to be a highly distinctive, relational form of entrepreneurial finance, filling an important funding gap for certain types of innovative UK start-ups. This article offers two main contributions to the literature. First, from an empirical perspective the work found a strong demand for equity crowdfunding from young growth-oriented entrepreneurs, many of whom can be classed as discouraged borrowers who eschew bank finance for fear of rejection. The primary attraction of this source of funding is speed and the apparent lack of 'strings' attached. A common facet of these highly 
improvisational entrepreneurs is their strong appetite for growth and low levels of risk aversion. Given the potential reputational consequences of failing to raise crowdfunding, this type of finance may be much less appealing to more risk-averse entrepreneurs.

Second, the paper's key theoretical contribution concerns the behavioural make-up of the entrepreneurs. It appears that crowdfunding appeals to highly experimental entrepreneurs resonant with the concept of entrepreneurial bricolage. Rather than submissively accepting resource constraints, as with most discouraged borrowers, these improvisational entrepreneurs instead become "encouraged borrowers" - creatively seizing crowdfunding as a means of overcoming their immediate financial obstacles. Given that the cognitive mind-set of these individuals -creative, spontaneous and improvisational- scholars may wish to incorporate bricolage theory as a theoretical lens explicating the crowdfunding process.

This work is not without limitations. As with most studies on crowdfunding, the cross-sectional perspective adopted limits our insights, particularly in terms of the longer-term effects of successfully obtaining equity crowdfunding. Ideally future studies could also track the longerterm effects of crowdfunding on recipient ventures. Our focus on ventures that successfully completed campaigns limits the generalisability of the findings, especially since these firms are atypical 'success stories' rather than representative of all those who attempt the process. The platform heterogeneity noted merits much closer analysis than our sample affords. The gender imbalance of the entrepreneurs is also worthy of further investigation. We hope that this inductive empirical study will stimulate others to tackle the growing research agenda surrounding this rapidly growing disruptive form of entrepreneurial finance. 


\section{References}

Ahlers, G. K., Cumming, D., Günther, C., \& Schweizer, D. (2015). Signalling in equity crowdfunding. Entrepreneurship Theory and Practice, 39(4), 955-980.

Alexy, O. T., Block, J. H., Sandner, P., \& Ter Wal, A. L. (2012). Social capital of venture capitalists and start-up funding. Small Business Economics, 39(4), 835-851.

Atz, $U$ and Bholat, D. (2016) Peer-to-peer lending and financial innovation in the United Kingdom, Bank of England Staff Working Paper No. 598.

Baeck, P., Collins, L., \& Zhang, B. (2014). Understanding Alternative Finance: The UK Alternative Finance Industry Report 2014. London: Nesta.

Baker, T., Miner, A. S., \& Eesley, D. T. (2003). Improvising firms: Bricolage, account giving and improvisational competencies in the founding process. Research policy, 32(2), 255-276.

Baker, T., \& Nelson, R. E. (2005). Creating something from nothing: Resource construction through entrepreneurial bricolage. Administrative science quarterly, 50(3), 329-366.

Baum, J. A., \& Silverman, B. S. (2004). Picking winners or building them? Alliance, intellectual, and human capital as selection criteria in venture financing and performance of biotechnology startups. Journal of business venturing, 19(3), 411-436.

Beck, T., \& Demirguc-Kunt, A. (2006). Small and medium-size enterprises: Access to finance as a growth constraint. Journal of Banking \& finance, 30(11), 2931-2943.

Bellavitis, C., Filatotchev, I., Kamuriwo, D. S., \& Vanacker, T. (2017). Entrepreneurial finance: new frontiers of research and practice, Venture Capital, 19(1-2), 1-16.

Belleflamme, P., Lambert, T., \& Schwienbacher, A. (2013). Individual crowdfunding practices. Venture Capital, 15(4), 313-333.

Belleflamme, P., Lambert, T., \& Schwienbacher, A. (2014). Crowdfunding: Tapping the right crowd. Journal of Business Venturing, 29(5), 585-609.

Berger, A. N. \& Black, L.K. (2011). Bank size, lending technologies and small business finance. Journal of Banking and Finance, 35(3), 724-735.

Berger, A. N. \& Udell, G. F. (1998). The economics of small business finance: The roles of private equity and debt markets in the financial growth cycle. Journal of Banking \& Finance, 22(6), 613673.

Binks, M. R., Ennew, C. T., \& Reed, G. V. (1992). Information asymmetries and the provision of finance to small firms. International Small Business Journal, 11(1), 35-46.

Binks, M. R., \& Ennew, C. T. (1996). Growing firms and the credit constraint. Small Business Economics, 8(1), 17-25. 
Blaseg, D. \& Koetter, M. (2015). Friend or Foe? Crowdfunding Versus Credit when Banks are Stressed. Discussion Paper No. 8. Halle, Germany: Halle Institute for Economic Research (IWH).

Block, J., Hornuf, L., \& Moritz, A. (2016). Which updates during an equity crowdfunding campaign increase crowd participation?. Small Business Economics, 1-25.

British Business Bank. (2014). Equity Crowdfunding in the UK: Evidence from the Equity Tracker. Sheffield: British Business Bank.

British Business Bank (2017) Small Business Equity Tracker 2017. Sheffield: British Business Bank.

Brown, R., Mawson, S. and Rowe, A. (2017) Start-Ups, Networks and Equity Crowdfunding: A Processual Perspective, Industrial Marketing Management, forthcoming.

Brüderl, J., \& Preisendörfer, P. (1998). Network support and the success of newly founded business. Small Business Economics, 10(3), 213-225.

Bruton, G., Khavul, S., Siegel, D., \& Wright, M. (2015). New Financial Alternatives in Seeding Entrepreneurship: Microfinance, Crowdfunding, and Peer-to-Peer Innovations. Entrepreneurship Theory and Practice, 39(1), 9-26.

Carpenter, R. E. \& Petersen, B. C. (2002). Capital market imperfections, high-tech investment, and new equity financing. The Economic Journal, 112(477), F54-F72.

Carpentier, C. \& Suret, J-M. (2015). Canadian business angel perspectives on exit: A research note. International Small Business Journal, 33(5), 582-593.

Cassar, G. (2004). The financing of business start-ups. Journal of Business Venturing, 19(2), 261283.

Charmaz, K. (2014). Constructing grounded theory. Second Edition, London: Sage.

Cholakova, M. \& Clarysse, B. (2015). Does the Possibility to Make Equity Investments in Crowdfunding Projects Crowd Out Reward-Based Investments?. Entrepreneurship Theory and Practice, 39(1), 145-172.

Cole, R., \& Sokolyk, T. (2016). Who needs credit and who gets credit? Evidence from the surveys of small business finances. Journal of Financial Stability, 24, 40-60.

Collins, L., \& Pierrakis, Y. (2012). The venture crowd: Crowdfunding equity investment into business. London: Nesta.

Collewaert, V., \& Manigart, S. (2015). Valuation of Angel-Backed Companies: The Role of Investor Human Capital. Journal of Small Business Management.

Colombo, M. G., \& Grilli, L. (2007). Funding gaps? Access to bank loans by high-tech start-ups. Small Business Economics, 29(1-2), 25-46. 
Colombo, M. G., Franzoni, C., \& Rossi-Lamastra, C. (2015). Internal social capital and the attraction of early contributions in crowdfunding. Entrepreneurship Theory and Practice, 39(1), 75-100.

Cope, J. (2005). Researching entrepreneurship through phenomenological inquiry: philosophical and methodological issues. International Small Business Journal, 23(2), 163-189.

Cordova, A. Dolci, J., \& Gianfrate, G. (2015) Crowdfunding: Toward the Democratization of Innovation Financing, In Archibugi, D.\& Filippetti, (Eds) "The Handbook of Global Science, Technology, and Innovation", John Wiley \& Sons, New York.

Cowling, M., Liu, W., \& Ledger, A. (2012). Small business financing in the UK before and during the current financial crisis. International Small Business Journal, 30(7), 778-800.

Cowling, M., Liu, W., Minniti, M., \& Zhang, N. (2016). UK credit and discouragement during the GFC. Small Business Economics, 47(4), 1049-1074.

Cumming, D. J., \& Vismara, S. (2016). De-segmenting research in entrepreneurial finance, Venture Capital, 19(1-2), 19-27.

Drover, W., Busenitz, L., Matusik, S., Townsend, D., Anglin, A., \& Dushnitsky, G. (2017). A Review and Road Map of Entrepreneurial Equity Financing Research: Venture Capital, Corporate Venture Capital, Angel Investment, Crowdfunding, and Accelerators. Journal of Management, doi/abs/10.1177/0149206317690584.

Dubois, A., \& Gadde, L. E. (2002). Systematic combining: an abductive approach to case research. Journal of Business Research, 55(7), 553-560.

FCA (2015) A Review of the regulatory regime for crowdfunding and the promotion of nonreadily realisable securities by other media, Financial Conduct Authority, London.

Ferrando, A., \& Mulier, K. (2015). The real effects of credit constraints: Evidence from discouraged borrowers in the euro area. European Central Bank Working Paper Series, No 1842/August 2015.

Financial Times (2015). How growing businesses are playing to the crowd. London: Financial Times, 21/1/15.

Fisher, G. (2012). Effectuation, causation, and bricolage: a behavioral comparison of emerging theories in entrepreneurship research. Entrepreneurship Theory and Practice, 36(5), 1019-1051.

Fraser, S., Bhaumik, S. K., \& Wright, M. (2015). What do we know about entrepreneurial finance and its relationship with growth?. International Small Business Journal, 33(1), 70-88.

Freel, M., Carter, S., Tagg, S. \& Mason, C. (2012). The latent demand for bank debt: characterizing "discouraged borrowers". Small Business Economics, 38(4), 399-418. 
Fritsch, M., \& Storey, D. J. (2014). Entrepreneurship in a regional context: historical roots, recent developments and future challenges. Regional Studies, 48(6), 939-954.

Frydrych, D., Bock, A. J., Kinder, T., \& Koeck, B. (2014). Exploring entrepreneurial legitimacy in reward-based crowdfunding. Venture Capital, 16(3), 247-269.

Gerber, E. M., Hui, J. S., \& Kuo, P. Y. (2012, February). Crowdfunding: Why people are motivated to post and fund projects on crowdfunding platforms. In Proceedings of the International Workshop on Design, Influence, and Social Technologies: Techniques, Impacts and Ethics (Vol. 2, p. 11).

Gerber, E. M. \& Hui, J. (2013). Crowdfunding: Motivations and deterrents for participation. ACM Transactions on Computer-Human Interaction (TOCHI), 20(6), 34.

Giudici, G., Guerini, M., \& Rossi-Lamastra, C. (2017). Reward-based crowdfunding of entrepreneurial projects: the effect of local altruism and localized social capital on proponents' success. Small Business Economics, 1-18.

Gioia, D. A., Corley, K. G., \& Hamilton, A. L. (2013). Seeking qualitative rigor in inductive research notes on the Gioia methodology. Organizational Research Methods, 16(1), 15-31.

Graebner, M. E., Martin, J. A., \& Roundy, P. T. (2012). Qualitative data: Cooking without a recipe. Strategic Organization, 10(3), 276-284.

Guba, E. S. \& Lincoln, Y. S. (1994). Competing Paradigms in Qualitative Research. In N. K. Denzin \& Y. S. Lincoln (eds.), Handbook of Qualitative Research (pp. 105-117). London: Sage.

Han, L., Fraser, S., \& Storey, D. J. (2009). Are good or bad borrowers discouraged from applying for loans? Evidence from US small business credit markets. Journal of Banking \& Finance, 33(2), 415-424.

Harrison, R. (2013). Crowdfunding and the revitalisation of the early stage risk capital market: catalyst or chimera?. Venture Capital, 15(4), 283-287.

Healy, M. \& Perry, C. (2000). Comprehensive criteria to judge validity and reliability of qualitative research within the realism paradigm. Qualitative Market Research: An International Journal, 3(3), 188-126.

Hellmann, T. \& Puri, M. (2002). Venture capital and the professionalization of start-up firms: Empirical evidence. The Journal of Finance, 57(1), 169-197.

Hemer, J. (2011). A snapshot on crowdfunding (No. R2/2011). Working papers firms and region. Karlsruhe, Germany: Fraunhofer ISI.

Hillman, A.J. \& Dalziel, T. (2003). Boards of directors and firm performance: Integrating agency and resource dependence perspectives. Academy of Management Review, 28(3), 383-396. 
Hjorth, D., Holt, R., \& Steyaert, C. (2015). Entrepreneurship and process studies. International Small Business Journal, 33(6), 599-611.

Hsu, D. H. (2004). What do entrepreneurs pay for venture capital affiliation?. The Journal of Finance, 59(4), 1805-1844.

Isenberg, D. (2012). The road to crowdfunding hell. Harvard Business Review Blog, Available at: https://hbr.org/2012/04/the-road-to-crowdfunding-hell/

Kaplan, S. N., \& Strömberg, P. (2003). Financial contracting theory meets the real world: An empirical analysis of venture capital contracts. The Review of Economic Studies, 70(2), 281-315.

Kon, Y. \& Storey, D. J. (2003). A theory of discouraged borrowers. Small Business Economics, 21(1), 37-49.

Kuppuswamy, V., \& Bayus, B. L. (2017). Does my contribution to your crowdfunding project matter?. Journal of Business Venturing, 32(1), 72-89.

Langley, P., \& Leyshon, A. (2017). Capitalizing on the crowd: The monetary and financial ecologies of crowdfunding. Environment and Planning A, 49(5), 1019-1039.

Lee, N., Sameen, H., \& Cowling, M. (2015). Access to finance for innovative SMEs since the financial crisis. Research policy, 44(2), 370-380.

Lee, N., \& Brown, R. (2017). Innovation, SMEs and the liability of distance: the demand and supply of bank funding in UK peripheral regions. Journal of Economic Geography, 17(1), 233260.

Leitch, C. M., Hill, F. M., \& Harrison, R. T. (2010). The philosophy and practice of interpretivist research in entrepreneurship: Quality, validation, and trust. Organizational Research Methods, 13(1), 67-84.

Lehner, O. M. (2013). Crowdfunding social ventures: a model and research agenda. Venture Capital, 15(4), 289-311.

Lehner, O. M., Grabmann, E., \& Ennsgraber, C. (2015). Entrepreneurial implications of Crowdfunding as alternative funding source for innovations. Venture Capital, doi:10.1080/13691066.2015.1037132.

Lin, M., \& Viswanathan, S. (2015). Home bias in online investments: An empirical study of an online crowdfunding market. Management Science, 62(5), 1393-1414.

Macht, S. A. \& Weatherston, J. (2014). The Benefits of Online Crowdfunding for Fund-Seeking Business Ventures. Strategic Change, 23(1-2), 1-14.

Martin, P. Y., \& Turner, B. A. (1986). Grounded theory and organizational research. The journal of applied behavioral science, 22(2), 141-157. 
Martin, R., Berndt, C., Klagge, B., \& Sunley, P. (2005). Spatial proximity effects and regional equity gaps in the venture capital market: evidence from Germany and the United Kingdom. Environment and Planning A, 37(7), 1207-1231.

Mason, C., \& Brown, R. (2013). Creating good public policy to support high-growth firms. Small Business Economics, 40(2), 211-225.

Mason, C. M. \& Harrison, R. T. (2015). Business angel investment activity in the financial crisis: UK evidence and policy implications. Environment and Planning C: Government and Policy, 33, 43-60.

Mollick, E. (2014). The dynamics of crowdfunding: An exploratory study. Journal of Business Venturing, 29(1), 1-16.

Moritz, A., Block, J., \& Lutz, E. (2015). Investor communication in equity-based crowdfunding: a qualitative-empirical study. Qualitative Research in Financial Markets, 7(3), 309-342.

Moritz, A., \& Block, J. H. (2016). Crowdfunding: A literature review and research directions. In Bruntje, D. and Gajda, O. (Eds) Crowdfunding in Europe: State of Art in Theory and Practice, pp. 25-53, Springer International Publishing.

Myers, S. C. \& Majluf, N. S. (1984). Corporate financing and investment decisions when firms have information that investors do not have. Journal of Financial Economics, 13(2), 187-221.

Nesta (2016) Pushing Boundaries: The 2015 UK Alternative Finance Industry Report, National Endowment for Technology, Science and Arts: London.

North, D., Baldock, R., \& Ullah, F. (2013). Funding the growth of UK technology-based small firms since the financial crash: are there breakages in the finance escalator?. Venture Capital, 15(3), 237-260.

Ordanini, A., Miceli, L., Pizzetti, M., \& Parasuraman, A. (2011). Crowd-funding: transforming customers into investors through innovative service platforms. Journal of Service Management, 22(4), 443-470.

Patton, M. Q. (2002). Qualitative Research and Evaluation Methods (3rd ed.). Thousand Oaks, CA: Sage.

Parker, L. D., \& Roffey, B. H. (1997). Methodological themes: back to the drawing board: revisiting grounded theory and the everyday accountant's and manager's reality. Accounting, Auditing \& Accountability Journal, 10(2), 212-247.

Pichler, F, \& Tezza, I. (2016). "Crowdfunding as a New Phenomenon: Origins, Features and Literature Review." In Bottiglia, R. \& Pichler, F. (Eds) Crowdfunding for SMEs: A European Perspective, pp. 5-43. London: Palgrave Macmillan.

Politis, D. (2008). Business angels and value added: what do we know and where do we go?. Venture Capital, 10(2), 127-147. 
Ralcheva, A., \& Roosenboom, P. (2016). On the Road to Success in Equity Crowdfunding. Working Paper, Rotterdam School of Management, Erasmus University.

Riding, A. L., Dal Cin, P., Duxbury, L., Haines, G., \& Safrata, R. (1993). Informal Investors in Canada: The Identification of Salient Characteristics. Ottawa: Carleton University.

Schweinbacher, A. \& Larralde, B. (2012). Crowdfunding of Small Entrepreneurial Ventures. In D. Cumming (ed.), Handbook of Entrepreneurial Finance. New York: Oxford University Press.

Short, J. C., Ketchen, D. J., McKenny, A. F., Allison, T. H., \& Ireland, R. D. (2017). Research on Crowdfunding: Reviewing the (Very Recent) Past and Celebrating the Present. Entrepreneurship Theory and Practice, 41(2), 149-160.

Signori, A., \& Vismara, S. (2016). Returns on investments in equity crowdfunding (SSRN Working Paper Nr. 2765488).

Sørensen, M. (2007). How smart is smart money? A two-sided matching model of Venture Capital. The Journal of Finance, 62(6), 2725-2762.

Stanko, M. A., \& Henard, D. H. (2017). Toward a better understanding of crowdfunding, openness and the consequences for innovation. Research Policy, 46(4), 784-798.

Street, C. T. \& Cameron, A. F. (2007). External relationships and the small business: A review of small business alliance and network research. Journal of Small Business Management, 45(2), 239-266.

Suddaby, R., Bruton, G. D., \& Si, S. X. (2015). Entrepreneurship through a qualitative lens: Insights on the construction and/or discovery of entrepreneurial opportunity. Journal of Business Venturing, 30(1), 1-10.

Surowiecki, J. (2004). The wisdom of crowds: Why the many are smarter than the few and how collective wisdom shapes business, economies, societies and nations little. New York: Anchor Books.

Udell, G. F. (2015). SME Access to Intermediated Credit: What Do We Know, and What Don't We Know?. Reserve Bank of Australia, Conference Volume.

Vulkan, N., Åstebro, T., \& Sierra, M. F. (2016). Equity crowdfunding: A new phenomena. Journal of Business Venturing Insights, 5, 37-49.

Vismara, S. (2016a). Equity retention and social network theory in equity crowdfunding. Small Business Economics, 46(4), 579-590. 
Vismara, S. (2016b). Information cascades among investors in equity crowdfunding. Entrepreneurship Theory and Practice, DOI 10.1111/etap.12261

Welter, C., Mauer, R., \& Wuebker, R. (2016) Bridging Behavioral Models and Theoretical Concepts: Effectuation and Bricolage in the Opportunity Creation Framework, Strategic Entrepreneurship Journal, 10:5-20.

Wijbenga, F. H., Postma, T. J., and Stratling, R. (2007). The influence of the venture capitalist's governance activities on the entrepreneurial firm's control systems and performance. Entrepreneurship Theory and Practice, 31(2), 257-277.

Wiltbank, R. E. (2009). Siding with the Angels: Business Angel investing-promising outcomes and effective strategies. London: Nesta.

World Bank (2013) Crowdfunding's potential for the developing world. Washington DC: World Bank.

Wright, M., Roper, S., Hart, M., \& Carter, S. (2015a). Joining the dots: Building the evidence base for SME growth policy. International small business journal, 33(1), 3-11.

Wright, M., Hart, M., \& Fu, K. (2015b). A Nation of Angels: Assessing the impact of angel investing across the UK. Enterprise Research Centre. 


\section{Figures}

Figure 1. Age of sample firms

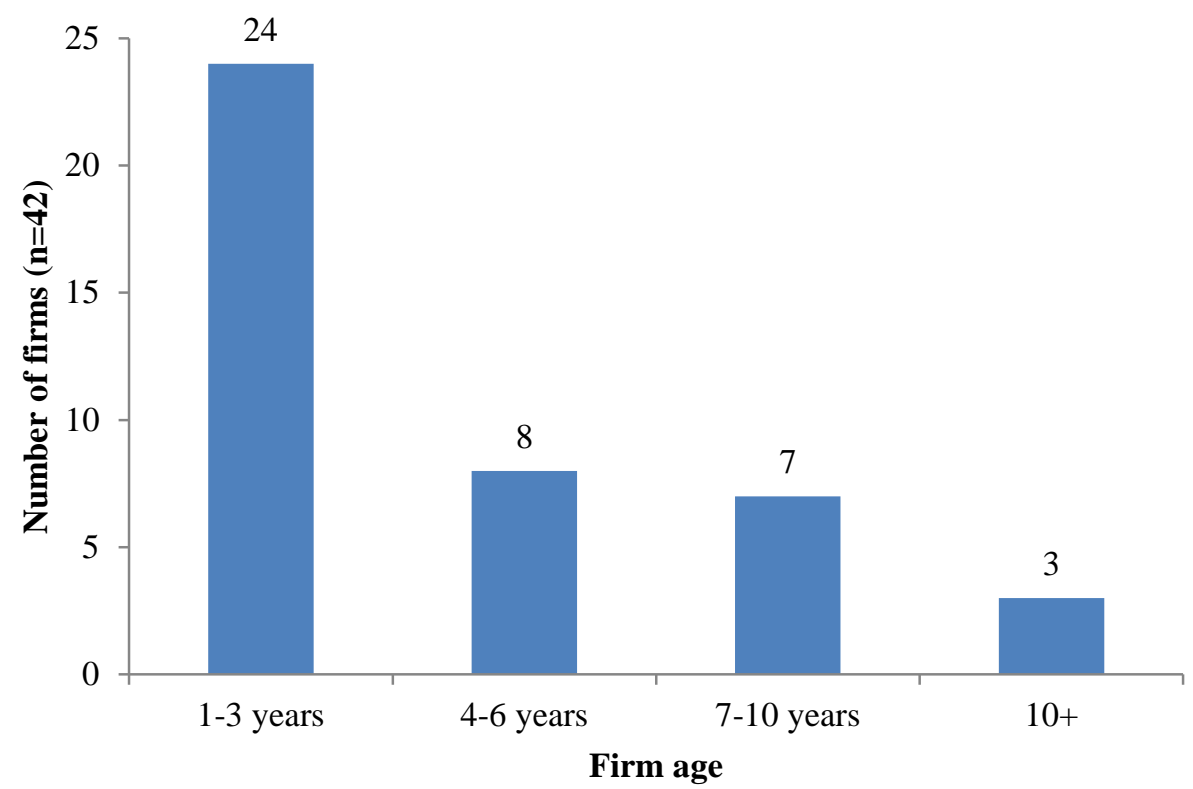

Figure 2. Sectoral breakdown of sample firms

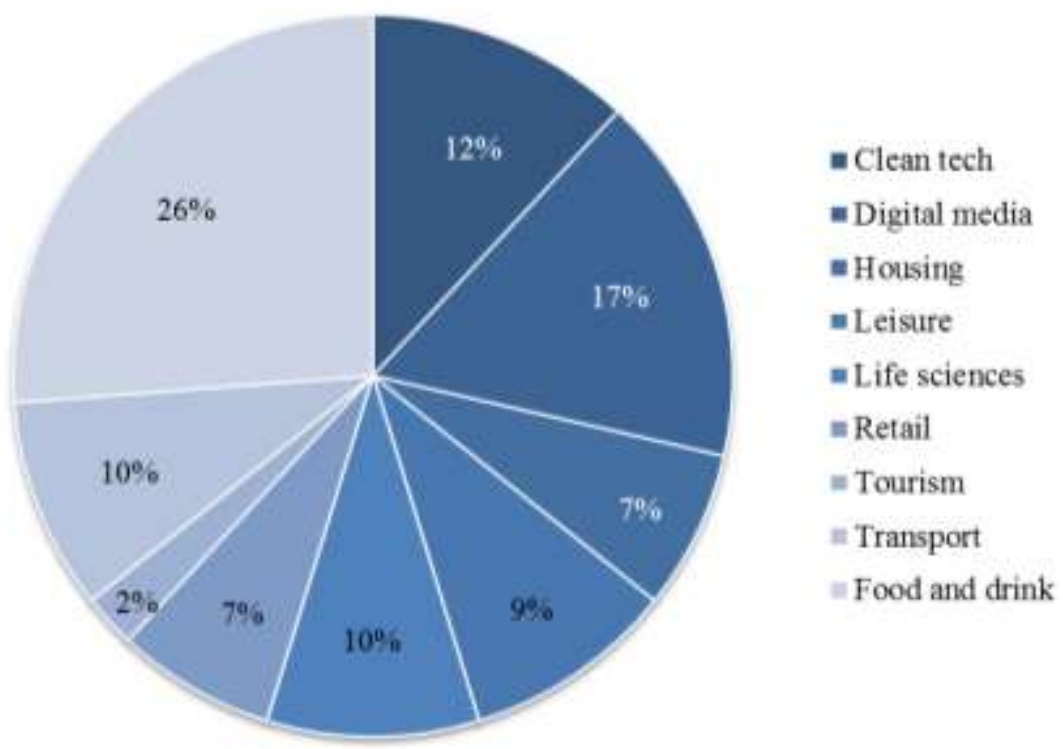


Figure 3. Geographical distribution of sample firms

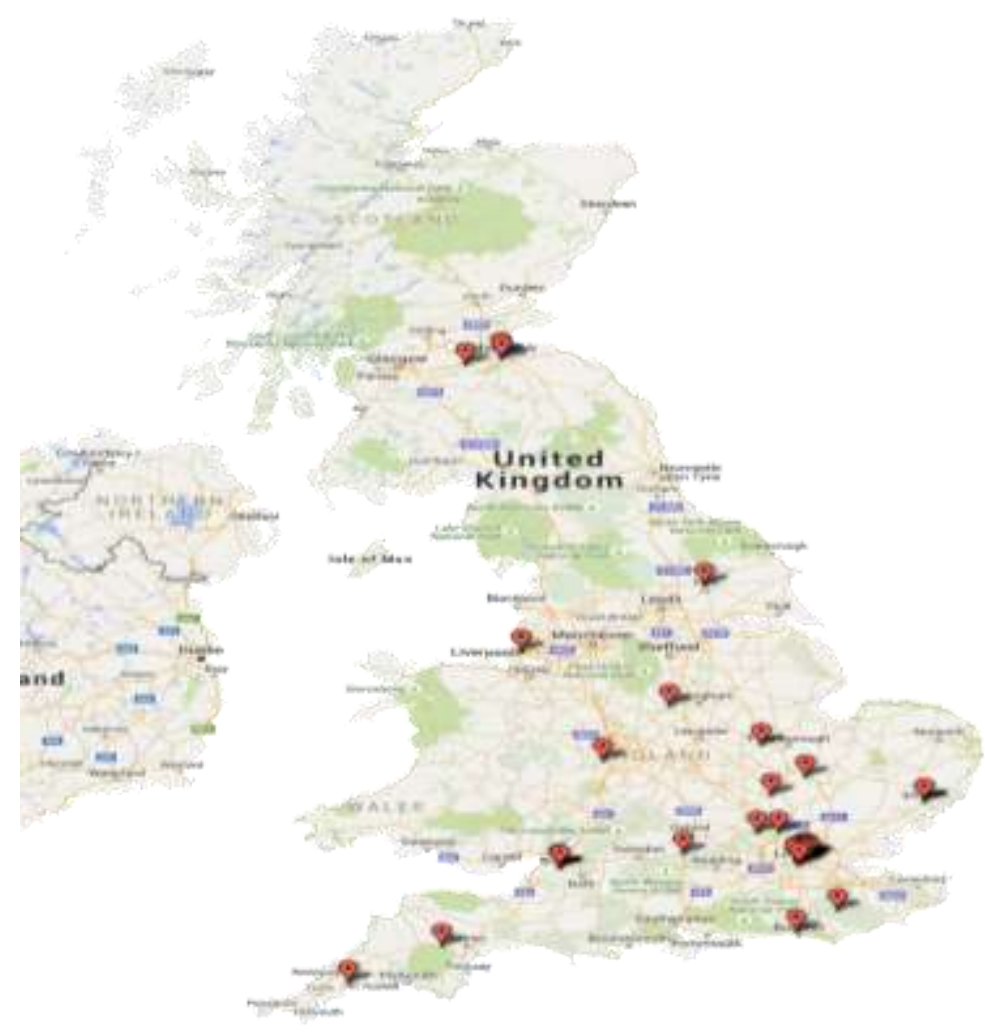

Figure 4. Financing raised

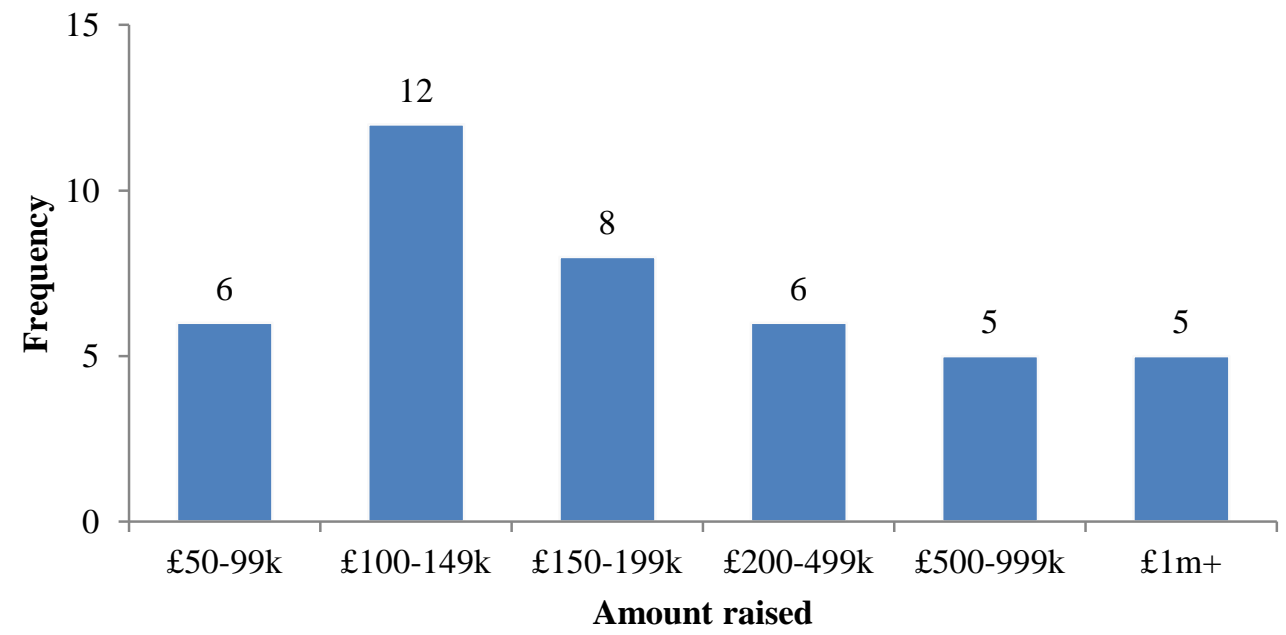

